DOI https://doi.org/10.30525/978-9934-26-111-4-52

\title{
ВПЛИВ ОРГАНІЧНОГО ЗЕМЛЕРОБСТВА НА ЧИСЕЛЬНІСТЬ МІКРОАРТРОПОД У ЧОРНОЗЕМАХ ТИПОВИХ ЛІВОБЕРЕЖЖЯ ЛІСОСТЕПУ УКРАЇНИ
}

\author{
Резнік C. В. \\ аспірант кафедри трунтознавства \\ Харківський національний аграрний університет імені В. В. Докучаєва \\ Гавва Д. В. \\ кандидат сільськогосподарських наук, \\ дочент кафедри трунтознавства \\ Харківський національний аграрний університет імені В. В. Докучаєва \\ Ковалжи Н. I. \\ викладач II категорії \\ Відокремлений структурний підрозділ \\ «Житлово-комунальний фаховий коледж Харківського національного \\ університету міського господарства \\ імені О. М. Бекетова» \\ м. Харків, Украӥна
}

Серед безхребетних грунтової біоти колемболи (Collembola) та нижчі панцерні кліщі-орібатиди (Acari: Oribatida) виділяються своїм різноманіттям, чисельністю (до сотень тисяч екз/дм³), пристосувальними функціями. Більшість із цих педобіонтів представлена сапрофагами. Їх просторовий розподіл розрізняється щодо локальної ділянки, біогеоценозу, ландшафту або регіону [1].

Тваринний світ грунтів різноманітний по видовому складу, а його біомаса набагато перевищує масу усього тваринного населення Землі. Найбільш численна група членистоногих, серед яких постійно відкриваються усі нові і нові види, раніше невідомі науці. Серед членистоногих найбільше поширення має клас комах, якого припадає на частку більше $70 \%$ усіх видів. Дорослі комахи (імаго) і їх личинки $\epsilon$ постійними мешканцями усіх типів грунтів. У співтоваристві з різноманітними групами усіх живих організмів вони здатні забезпечувати стійку рівновагу біологічних процесів в грунті, що обумовлюють іiі родючість [2]. 
Характерною рисою сучасного рільництва $є$ наявність сівозмін, при яких на значних територіях, як правило, щорічно різко міняється видовий склад і характер рослинного покриву. Наслідком цього $\epsilon$ зміна і гідротермічного режиму грунту [3]. У таких умовах серед грунтонаселяючих членистоногих, для більшості з яких характерна низька міграційна здатність, можуть виживати тільки види, що мають високу міру екологічної пластичності відносно кормових рослин або здатних виживати при тривалій відсутності рослинної їжі. Цим пояснюється відносна бідність видового складу i скорочення чисельності грунтонаселяючих тварин на оброблюваних землях в порівнянні з цілинними ділянками [4].

Досліджувалися чорноземи типові глибокі середньосуглинкові на лесі Лівобережжя Лісостепу України у межах Зіньківського р-ну. Полтавської обл. Для досліджень обрано такі об'єкти (табл. 1): органічна система землеробства (ОС3 сидерат); органічна система землеробства (ОСЗ компост 20 т/га), інтенсивна система землеробства (IC3 мінеральні добрива), отримані дані порівнювалися із показниками отриманими на переліжній ділянці, що не оброблялася понад $30 \mathrm{p}$. Відбір зразків (0-10, 10-20, 20-30, 30-40 см) проводився в першій декаді травня, серпня та листопада 2018-2020 pp.

Таблиця 1

Сівозміна і система удобрення у період досліджень

\begin{tabular}{|c|c|c|c|}
\hline Варіант/рік & 2018 & 2019 & 2020 \\
\hline $\begin{array}{c}\text { Органічна } \\
\text { система } \\
\text { землеробства } \\
\text { (сидерат) } \\
\end{array}$ & $\begin{array}{l}\text { вика яра на } \\
\text { сидерат }\end{array}$ & $\begin{array}{c}\text { озима } \\
\text { пшениця } \\
\text { (сидерат, 15т/га } \\
\text { зеленої маси) } \\
\end{array}$ & $\begin{array}{c}\text { зимуючий } \\
\text { горох - пересів } \\
\text { кукурудза на } \\
\text { силос } \\
\end{array}$ \\
\hline Переліг & \multicolumn{3}{|c|}{ різнотряв’я } \\
\hline $\begin{array}{c}\text { Органічна } \\
\text { система } \\
\text { землеробства } \\
\text { (компост) } \\
\end{array}$ & $\begin{array}{c}\text { кукурудза на } \\
\text { зерно (20т/га } \\
\text { компосту із гною } \\
\text { ВРX) } \\
\end{array}$ & овес & $\operatorname{cog}$ \\
\hline $\begin{array}{c}\text { Інтенсивна } \\
\text { система } \\
\text { землеробства }\end{array}$ & $\begin{array}{c}\text { кукурудза на } \\
\text { зерно }\left(\mathrm{N}_{130} \mathrm{P}_{30} \mathrm{~K}_{30}\right)\end{array}$ & $\begin{array}{c}\text { соняшник } \\
\left(\mathrm{N}_{35} \mathrm{P}_{15} \mathrm{~K}_{30}\right)\end{array}$ & $\begin{array}{c}\text { кукурудза } \\
\left(\mathrm{N}_{130} \mathrm{P}_{30} \mathrm{~K}_{30}\right)\end{array}$ \\
\hline
\end{tabular}

Відбір зразків проводився в першій декаді травня методом ріжучого кільця циліндрами Н. А. Качинського. Збір матеріалу, транспортування, вигонка колембол і орибатид із проб та їх фіксацію проводили згідно із загальноприйнятими методиками грунтово-зоологічних досліджень [5]. 


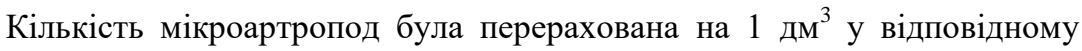
шарі грунту.

Аналізуючи дані (табл. 2) слід відмітити значне зниження чисельності колембол у варіантах агрогенного використання чорноземів типових (56-22 екз/дм $\left.{ }^{3}\right)$ порівняно із перелогом (11159 екз/дм ${ }^{3}$ ). Серед грунтів, що обробляються найменшою чисельністю колембол характеризується варіант ОСЗ із застосуванням сидерату (5022 екз/дм $\left.{ }^{3}\right)$.

Таблиця 2

Чисельність Collembola (C) та Oribatida (A) у чорноземах типових залежно від системи землеробства, екз/дм ${ }^{3}$

\begin{tabular}{|c|c|c|c|c|}
\hline Варіант & $\begin{array}{c}\text { Глибина, } \\
\text { см }\end{array}$ & $\begin{array}{c}\text { Collembola, } \\
\text { екз/дм }{ }^{3}\end{array}$ & $\begin{array}{c}\text { Oribatida, } \\
\text { екз/дм }^{3}\end{array}$ & $\mathbf{A} / \mathbf{C}$ \\
\hline \multirow{4}{*}{$\begin{array}{c}\text { Органічна система } \\
\text { землеробства } \\
\text { (сидерат) }\end{array}$} & $0-10$ & 50 & 125 & 0,40 \\
\hline & $10-20$ & 47 & 70 & 0,67 \\
\hline & $20-30$ & 30 & 51 & 0,58 \\
\hline & $30-40$ & 22 & 51 & 0,43 \\
\hline \multirow{4}{*}{ Переліг } & $0-10$ & 101 & 43 & 2,34 \\
\hline & $10-20$ & 111 & 32 & 3,44 \\
\hline & $20-30$ & 71 & 27 & 2,60 \\
\hline & $30-40$ & 59 & 27 & 2,22 \\
\hline \multirow{4}{*}{$\begin{array}{c}\text { Органічна система } \\
\text { землеробства } \\
\text { (компост) }\end{array}$} & $0-10$ & 55 & 75 & 0,73 \\
\hline & $10-20$ & 56 & 53 & 1,06 \\
\hline & $20-30$ & 39 & 28 & 1,36 \\
\hline & $30-40$ & 29 & 27 & 1,06 \\
\hline \multirow{4}{*}{$\begin{array}{c}\text { Інтенсивна система } \\
\text { землеробства } \\
\text { (мінеральні добрива) }\end{array}$} & $0-10$ & 50 & 82 & 0,61 \\
\hline & $10-20$ & 56 & 89 & 0,63 \\
\hline & $20-30$ & 37 & 86 & 0,44 \\
\hline & $30-40$ & 49 & 53 & 0,94 \\
\hline
\end{tabular}

Зазвичай чисельність колембол з глибиною знижується однак у зв'язку із пересиханням верхнього 0-10-сантиметрового шару грунту проявляється їх здатність до вертикальних міграцій, що призводить до збільшення їх чисельності у шарі 10-20 см, що свідчить про їх вимогливість до гідротермічних умов. Також слід відмітити можливість збільшення іх чисельності у більш глибоких шарах у варіанті IC3, що пов'язано із оборотом пласта і заорюванням рослинних решток на глибину 20-30 см.

Згідно отриманих даних агрогенні грунти характеризуються значно вищою чисельністю орибатид (125-27 екз/дм³ ) порівняно із перелогом 
(43-27 екз/дм ${ }^{3}$. Найвищі показники чисельності зафіксовано у варіанті ОСЗ сидерат (125-51 екз/дм $\left.{ }^{3}\right)$, що свідчить про вимогливість панцирних кліщів до наявності свіжих органічних решток. Розподіл орибатид за глибинами має подібні до чисельності колембол тенденції.

Висновки. Сільськогосподарське використання грунтів призводить до значних змін показників загальної біологічної активності зокрема $\mathrm{i}$ чисельності мікроартропод. Характер і ступінь вираження цих змін залежать від системи землеробства, сезону і глибини відбору.

Отримані дані свідчать про зменшення чисельності колембол і одночасного збільшення чисельності орибатид у грунтах агроценозів, а ï співвідношення (Acari/Collembola) становить 0,5-1,4 тоді як під перелогом навпаки чисельність колембол більша 2,2-3,4. Розподіл за глибинами відбувається у відповідності до гідротермічних показників грунту, наявності рослинних решток і агротехнічних заходів.

\section{Література:}

1. Меламуд В. В., Рукавець С. В. Різноманіття грунтових мікроартропод природних зон Західного Полісся України. Біорізноманіття та роль тварин в екосистемах: Матеріали VI Міжнародної наукової конференції. Дніпропетровськ: Вид-во ДНУ, 2011. С. 193-195.

2. Рєзнік С.В., Гавва Д. В., Новосад К.Б., Сотников Ю.О. Динаміка чисельності мікроартропод у чорноземах типових за умов різного агрогенного та постагрогенного використання. Вісник Харківського національного аграрного університету ім. В. В. Докучаєва. Серія «Грунтознавство, агрохімія, землеробство, лісове господарство, екологія грунтів». № 2. Харків: ХНАУ, 2015. С. 66-76.

3. Guerra, C.A., Heintz-Buschart, A., Sikorski, J. et al. Blind spots in global soil biodiversity and ecosystem function research. Nat Commun 11, 3870 (2020). https://doi.org/10.1038/s41467-020-17688-2.

4. Wang, S., Chen, H., Tan, Y. et al. Fertilizer regime impacts on abundance and diversity of soil fauna across a poplar plantation chronosequence in coastal Eastern China. Sci Rep 6, 20816 (2016). https://doi.org/10.1038/srep20816.

5. Гиляров М. С. Учет мелких членистоногих (микрофауны) и нематод. Методы почвенно-зоологических исследований. Москва: Наука, 1975. С. 280. 